\title{
Alpha-1 Microglobulin Measurement
}

National Cancer Institute

\section{Source}

National Cancer Institute. Alpha-1 Microglobulin Measurement. NCI Thesaurus. Code C100461.

The determination of the amount of alpha-1 microglobulin present in a sample. 